\title{
Grammatical Elements as Meta-Language Tools for Teaching the Italian Language
}

\author{
Msc. Floriana Pango \\ "Eqrem Çabej" University, Department of Foreign Languages, "Eqrem Çabej" University, Albania \\ Email address: floriana_mera@yahoo.it \\ Msc. Aida Lamaj \\ "Eqrem Çabej" University, Department of Foreign Languages, "Eqrem Çabej" University, Albania \\ Email address: aida_lamaj@yahoo.it
}

\section{Doi:10.5901/ajis.2015.v4n3s1p486}

\section{Abstract}

The purpose of this paper is to describe and classify the various issues related to teaching and learning of grammatical Italian rules, to Albanian pupils and students. In the multiplicity of problems associated to the transmission of grammatical elements of each language, we will focus on a very important step as meta-language: language used to transmit foreign language grammar. Thoughts on the role of a meta-language bring us to binomial oppositions, which are acceptable depending on the circumstances in which they are used and actualized. Meta-language as an essential element of this process often turns into the main weapon to achieve the objectives of the learning process. In this paper we have used theoretical researches in the field of teaching, especially in the twentieth century by foreigners and locals, and the data obtained from surveys and questionnaires conducted not only to teachers of Italian language at all levels of education, but also to pupils and students. Grammar, in a traditional context of teaching foreign languages, has offered an irreplaceable and exclusive aid only through teachers, while today the approach of grammar should be moved within a multidimensional linguistic communication.

Keywords: meta-language, Italian grammar, learning, linguistic and multi-dimensional communication.

\section{Introduction}

For all the time that humanity has accepted the existence of different codes in order to express notions, objects different points, realities perceived in a million of ways, it has existed even the interest to know deeply these codes, to make it as much realizable each view of this reality. A considerable part of these codes is grammar, as one of the main elements of each language. Naturally, in the course of centuries independently of prevalent trends, the grammar has taken the main part of the discussions, often acquiring even the spaces of other elements "with equal rights" for languages. Recently, together with the development of humans toward infinite horizons of knowledge, the grammar status during the acquisition of foreign languages, has changed, anyway it remains static the approach that the profound acquisition of each human language is unconceived without the deep knowledge of the appropriate grammar. It have been developed many debates toward the manner of knowledge transmission, related to grammar, in fact what has remained unchangeable is the wish to explore more and more, every day, techniques and manners to acquire more effectively in less time the grammar. In the majority of problematic related to the transmission of grammatical elements of each language, we will halt in a very important element such as meta-language: the language of language that is used to transmit the grammar of foreign language.

The approaches on the role of meta-language lead to a dichotomy, which is acceptable in dependence of the situations where they are used and updated. Among the advantages we may mention the fact that in the phase of arranging the grammatical knowledge, the meta-language may accelerate what is called the reflection and to rise even more the clarity given by schematism. On the other hand the appropriate time to acquire this terminology, the excessive importance that is given to the abstract reasoning on the language, the fact that many teachers use it intensively make a foreign language a double-edged blade. A pragmatic approach and not a dogmatic one to the problem may lead to a resolution and a partly new use of the meta-language. Above all the use of the use of the grammatical terminology of a foreign language is advised in a deep relation to a general, methodological shift. It is necessary for the teacher to be attentive to motivate the use of the meta-language through interferences that have the aim to determine effectiveness. An interesting role may be attributed to meta-language as an instrument to help the autonomy of the student due to the fact that the acquisition of this terminology makes it possible the exploit and the consultation of enormous texts. If this is a 
description in theoretical terms what happens in practical terms? Students have difficulties dealing with teachers that work intensively on the way of study; that promote the developments of language abilities; that make it difficult the communicative dimension of language study; that aimed the activation and education towards the use of both brain's modalities, owing to the kind of teaching materials made available; that apply strategies of inductive kind and not only deductive; that propose and pretend a study and a review at home and in class constant and stretched in time; that have the tendency to appreciate not only the product but even the way of learning and so on. On the other hand, on different realities, colleagues of other disciplines, ranging from cases similar to the Albanian language (mother tongue in our case), lead their work in a study based mainly on learning themes through a traditional type, causing methodological distortions and student's distraction. The grammar in a traditional context of teaching foreign languages offers an exclusive and crucial role only through the teacher, while today the approach toward grammar must be shifted in the reference of a multidimensional communication. In other words the teacher should be careful when dosing grammar in order not to base the didactic process more or less on this component.

Apart from the ascertainment that the proposed input should answer the criteria of understanding (Krashen), the process of acquisition by the student comes thanks to mechanisms that partly speed to teacher's control, but the latter will try to favor putting into practice appropriate strategies, establishing appropriate atmosphere, etc. The teacher may ask students to choose structures that need to be analyzed and submitted by the stage of globality, in order to activate the student's monitoring ability.

With the desire to drop the level of general theories on the situations assessed in complexity or assumed, and looking to be a little more descriptive, we can say that the levels of students we encounter every day in our auditoriums, meta-language often remains a dream, because in fact the students do not know the terminology neither in the mother tongue, in fact perhaps even an well- educated Italian does not recognize properly meta-language and will not be able to explain the function of "ne" (partial pronoun) in any sentence. The problem actually becomes more acute when we are "armed" with an arsenal grammatical terminology to an audience, which instead of processing data, should begin to teach as a new language.

This reflection would not be complete, if we will represent only facts, without reflecting and without giving a motivation toward a profound reflection for this problem: according to our opinion.

Firstly, as the foreign language is taught in third grade it would not be reasonable to pretend a thorough inconceivable of the meta-language, even though in this phase should be applied some elements of the terminology (those that are more used), but only if students know this terminology even in native language. Later, the grammatical terminology is adopted according to the age and the level of language acquisition. Concretely in one of the methods of Italian language used in the third grade, it is being taught to the students present perfect (passato prossimo) which is a composite tense, a concept which is being known for the student. On the other hand a big difficulty it is found in the use of the auxiliary verbs have and to be which are different from the Albanian language. In Albanian and Italian language the indicative has the same terminology but a problem is found in some tenses which are explained earlier in Italian language. Altogether it is not existent the infinitive. Gerundial forms into Albanian are formed by the past participle and not by the infinitive. Another grammatical element which represents difficulty during teaching is even the noun:

a) The problems of the terminology: noun-name

b) The absence of cases, a problem that lead to the use of a concept even more complicated such as the preposition; the cases function in Italian is held by the preposition (simple and composed) because the prepositions are necessary in the first steps of language acquisition to create first sentences (even those simpler) especially for children it is difficult to be absorbed all the prepositions in their multifunction.

c) In Albanian language the gender and noun forms (singularity vs. plurality) is defined by inflections while in Italian language this function is held by the article.

d) On the other hand the article into Albanian is part of the adjective while in Italian is part of the noun and it serves to show even the gender, inflections of nouns and its definiteness.

Secondly, the idea that to learn a foreign language, is right, the learner to shift his position as a learner to be redefined from that of a person who is on a receiving and of the teaching process to that of an open -minded child like a situation which is gradually acquainted with a new code and along with a corresponding grammatical terminology.

Thirdly, reflecting more during teaching grammatical syllabuses of foreign languages we have observed that the use of the parallels terminology facilitates the learning process of terminology, such as: referring to Italian language for a student is easier to learn and use in practice the term "composto" even where the use of this term is optional because there is another term more specific as futuro composto instead futuro anteriore, or preposizione semplice or composta instead preposizione articolata, ausiliare instead verbo, proposizione instead of exclusively used frase. 


\section{Conclusions}

1. The student must develop his skills in the use of language to communicate ideas with much more efficiency in concrete situations. The thematic diversity (age, culture, recreation, science) encourage the learner to rely on the use of grammar rules in an efficient and convenient communication.

2. Competence and capacity in learning a language, their reflection as similar to the owner of a language or their reciprocal report ratio between theory and examples are followed by the use of language in various communicative situations.

3. Tommy Thomason and Geoff Ward in "Tools, Not Rules Teaching Grammar in the Writing Classroom" emphasize the importance of linking learning grammar with speech and writing. They say "good grammar can contribute to clarity, understanding, fluidity and style. If we want students to use the language they must exercise to practice speaking and writing correctly and care about the good use of language.

\section{References}

Balboni, E. P. (2014). Quaderno della Ricerca dedicato al CLIL per Loescher Editore, Italia.

Ferreira, A. (2002), Imparare ed insegnare l'italiano come L2 -strumenti, metodologie, modelli ed approcci didattici, Bologna.

Hagege, C. (1996), L'enfant aux deux langues, Paris.

Mezzadri, M. (2003), I ferri del mestiere, Perugia

Rrokaj, Sh. (2011), Këndvështrime për mësimdhënien e gjuhës dhe letërsisë në shkollë, Tiranë.

Thomason, T and Ward, G. (2010) in Tools, Not Rules Teaching Grammar in the Writing Classroom, United State. 